\title{
Early Vegetation Development on an Exposed Reservoir: Implications for Dam Removal
}

\author{
Gregor T. Auble $\cdot$ Patrick B. Shafroth . \\ Michael L. Scott · James E. Roelle
}

Received: 14 January 2006/ Accepted: 1 September 2006

(C) Springer Science+Business Media, LLC 2007

\begin{abstract}
The 4-year drawdown of Horsetooth Reservoir, Colorado, for dam maintenance, provides a case study analog of vegetation response on sediment that might be exposed from removal of a tall dam. Early vegetation recovery on the exposed reservoir bottom was a combination of (1) vegetation colonization on bare, moist substrates typical of riparian zones and reservoir sediment of shallow dams and (2) a shift in moisture status from mesic to the xeric conditions associated with the pre-impoundment upland position of most of the drawdown zone. Plant communities changed rapidly during the first four years of exposure, but were still substantially different from the background upland plant community. Predictions from the recruitment box model about the locations of Populus deltoides subsp. monilifera (plains cottonwood) seedlings relative to the water surface were qualitatively confirmed with respect to optimum locations. However, the extreme vertical range of water surface elevations produced cottonwood seed regeneration well outside the predicted limits of drawdown rate and height above late summer stage. The establishment and survival of cottonwood at high elevations and the differences between the upland plant community and the community that had developed after four years of exposure suggest that vegetation recovery following tall dam removal will follow a trajectory very different from a simple reversal of the response to dam construction, involving not only long time scales of
\end{abstract}

G. T. Auble $(\bowtie) \cdot$ P. B. Shafroth · M. L. Scott

J. E. Roelle

United States Geological Survey, 2150 Centre Avenue,

Bldg. C, Fort Collins, CO 80526, USA

e-mail: greg_auble@usgs.gov establishment and growth of upland vegetation, but also possibly decades of persistence of legacy vegetation established during the reservoir to upland transition.

Keywords Colorado - Cottonwood - Dam removal . Drawdown - Horsetooth Reservoir - Recruitment box model · Reservoir margin - Riparian

\section{Introduction}

Although more than 450 dams have been removed in the United States in the past century, dam removal has only recently received significant attention from the scientific community (Beyer 2002, Hart and Poff 2002, Graf 2003). Reasons for dam removal include unsafe conditions or loss of function associated with aging or sediment-filled structures and, more recently, environmental restoration (Hart et al. 2002, Pohl 2002). Dam removal decisions involve a tradeoff of multiple socioeconomic and ecological costs and benefits (Stanley and Doyle 2003). Potential environmental consequences of dam removal include (1) benefits from restoring more natural flow and sediment regimes (Poff et al. 1997, Kondolf 1997) and (2) removing barriers that block fish passage (Lenhart 2003) and fragment the river corridor (Nilsson et al. 2005). Potential negative effects include the impacts of releasing stored, and possibly contaminated, sediment and enhancing dispersal of undesirable species (Bednarek 2001). The aspect of dam removal examined here is the ecological fate of the land under the former reservoir pool. Trajectories of vegetation response on lands exposed by dam removal influence higher-order responses such as 
human and wildlife use and biogeochemical processes (Shafroth et al. 2002). In some cases, restoration of predam vegetation may be a management goal. The extent to which this can be accomplished by natural colonization and subsequent vegetation change may significantly affect project costs. In some cases, natural colonization may be the default management action because of budgetary constraints, limited mandates, or lack of interest in restoration. Even in the absence of a specific restoration target for vegetation on the exposed surfaces, there are concerns about rapid dominance of these barren areas by undesirable, weedy, non-native species and the need to provide stabilizing vegetation to minimize erosion.

Several sources of information support projections of likely future vegetation on land exposed by a dam removal. The first source includes studies of the plant communities in the surrounding upland landscapes, in the riparian zones of rivers, and in the margins of lakes and reservoirs. The description of these communities and the controls on their composition, especially vegetation dynamics on disturbed, bare ground sites, provide a coarse identification of possible states for the former reservoir pool. There is also a significant literature examining vegetation dynamics within periodically exposed lake or reservoir shorelines illustrating the importance of intra- and inter-annual water level fluctuation (Keddy and Rznicek 1982, 1986, Hill et al. 1998) and positive relations between species richness and both total cover and substrate fineness (Nilsson and Keddy 1988, Nilsson et al. 1997).

Studies of floodplain vegetation colonization and dynamics provide information on likely pioneer species and subsequent changes associated with fluvial processes and geomorphic surfaces within river bottomlands in many regions. For example, Friedman et al. (1996) described patterns of vegetation change on the floodplain of Plum Creek in eastern Colorado, where species richness peaked at intermediate ages, older and higher surfaces were increasingly dominated by rhizomatous perennials, and the overall species list was $36 \%$ non-native. In the western United States, much of the focus on relations between streamflow and riparian vegetation has centered on cottonwood, which is the structurally dominant native tree. Populus deltoides subsp. monilifera (plains cottonwood) is a pioneer species with a relatively narrow regeneration niche. The requirements for a bare, moist surface with limited drawdown following germination have been represented in a formal recruitment box model describing the floodplain locations and patterns of water stage where establishment is likely for $P$. deltoides subsp. monilifera and other species of cottonwood and willow with similar establishment requirements (Mahoney and Rood 1998, Rood et al. 2005). This model is a clear example of how expectations derived from the study of riparian plant distributions and life history requirements can be used to inform an assessment of recolonization of the former reservoir pool following dam removal.

The second general source of information is observations from actual dam removals (Bednarek 2001, Stanley and Doyle 2002). In relatively few cases have environmental effects been evaluated following dam removal, and these studies were all of dams less than $17 \mathrm{~m}$ tall in relatively humid settings (Hart et al. 2002). Quantitative analysis of vegetation response to actual dam removal is rare, although two recent studies examine vegetation colonization and succession within the former reservoir pools of small dams removed in Wisconsin (Lenhart 2000, Orr and Stanley 2006).

A final source of information is case studies from alterations at least partially analogous to dam removal, including breaching of beaver and debris dams, accidental human dam failures, and dam maintenance activities. For example, the episodic release of a large sediment pulse from dam maintenance has been analyzed as a surrogate for the downstream effects of the type of sediment pulse that might be produced by dam removal (Wohl and Cenderilli 2000, Zuellig et al. 2002). In this study, we examine vegetation colonization and early dynamics on areas exposed when a reservoir was drained for four years to facilitate dam repairs. We describe vegetation pattern in terms of time since exposure in this analog to dam removal, in order to supplement the sparse empirical database available to scientists, resource managers, and policy makers involved in dam removal evaluations.

\section{Study Site}

Horsetooth Reservoir is located in the foothills of the Rocky Mountains, $7 \mathrm{~km}$ west of Fort Collins, Colorado, in the transition zone between two physiographic provinces: the Colorado Piedmont subdivision of the Great Plains to the east and the southern Rocky Mountains to the west (Fenneman 1931). At an elevation of $1,655 \mathrm{~m}$ asl, the study site is in the rain shadow of the Rocky Mountains, approximately $70 \mathrm{~km}$ east of the Continental Divide; mean annual precipitation ranges from $36-40 \mathrm{~cm}$, more than $70 \%$ of which falls between April and September. Summer in the study area is typically hot, with a mean July maximum of $29^{\circ} \mathrm{C}$. Fall is cool and typically dry, punctuated occasionally by wet and sometimes heavy upslope 
snowstorms. Winter is characteristically dry and cool to cold with a mean minimum January temperature of $-3.2^{\circ} \mathrm{C}$ and extreme winter minimum temperatures as low as $-40^{\circ} \mathrm{C}$ (Hansen et al. 1978).

The transition zone between these physiographic regions, described by Marr (1961) as the GrasslandLower Montane ecotone, is characterized by a rapid change in elevation and a shift from grassland to forest. In this transition zone, localized differences in soil primarily determine the dominant vegetation type at a given location. Grasslands characteristically dominate deeper, finer textured soils, transitioning to shrublands and open stands of ponderosa pine (Pinus ponderosa) on shallow, rocky soils and fractured rock outcrops (Marr 1961). Existing vegetation on the steep slopes and ridges above the high water line of Horsetooth Reservoir, matches the transition from shrublands dominated by Cercocarpus montanus and Rhus trilobata (Rhus aromatica, Great Plains Flora Association 1986) to a Pinus ponderosa community type described by Peet (1981) for rocky slopes below 1,700 m. This open, xeric forest type is characterized by widely scattered Pinus ponderosa with a grass-dominated understory. Despite xeric site conditions, understory species diversity and cover are relatively high. Cercocarpus montanus, Rhus trilobata, and Yucca glauca dominate the shrub layer, while Stipa comata, Bromus tectorum, Helianthus pumilus, Sporobolus cryptandrus, Bouteloua hirsuta, and Verbascum thapsus are important in the herbaceous layer (Peet 1981). As seen in portions of the valley not inundated by Horsetooth Reservoir, grasslands dominate toeslopes above the valley margins as well as the valley floor, where finertextured soils accumulate to greater depths. These grasslands are characteristically dominated by Agropyron smithii, Andropogon scoparius, Bouteloua curtipendula, B. gracilis, Bromus tectorum, and Stipa comata (Hansen and Dahl 1957). Narrow valley floors typically support scattered stands of riparian shrubs and trees, including Salix irrorata, Betula occidentalis, Populus deltoides subsp. monilifera, and Salix amygdaloides (Marr 1961).

The reservoir is situated between two sharp ridge crests or hogbacks, formed by steeply dipping layers of shales and sandstones. The reservoir is approximately $10 \mathrm{~km}$ long, and is formed by four large, earth-filled dams; Horsetooth Dam closes the northern end of the valley, and Soldier Canyon, Dixon Canyon, and Spring Canyon Dams close breaches in the eastern hogback ridge created by pre-existing cross-valley drainages. The structural heights of the dams are 47,69,73, and $67 \mathrm{~m}$, respectively. Construction of the four dams creating Horsetooth Reservoir occurred between 1946 and 1949.
With a total off-channel storage capacity of approximately $1.9 \times 10^{8} \mathrm{~m}^{3}$, Horsetooth is one of 12 storage reservoirs built as part of the Colorado-Big Thompson Project, which stores, regulates, and diverts approximately $3.2 \times 10^{8} \mathrm{~m}^{3}$ of water annually from the Colorado River headwaters on the west slope of the Continental Divide to the more heavily populated east slope. The project provides water for irrigated agriculture, municipal and industrial use, hydroelectric power generation, and water-based recreation. Discovery of sinkholes and increased seepage from the reservoir prompted a dam modernization project and reservoir drawdown that began in the fall of 2000 (B. Boaz personal communication, U.S. Bureau of Reclamation 2005).

\section{Methods}

\section{Field Sampling}

We sampled vegetation along 13 transects that began $5 \mathrm{~m}$ into upland vegetation (above the reservoir's high water mark of $1654.6 \mathrm{~m}$ above sea level) and extended down slope (perpendicular to the shoreline) to an elevation of $1621.5 \mathrm{~m}$ asl. Below $1621.5 \mathrm{~m}$ asl, the reservoir begins to separate into distinct pools with different water surface elevations. Transects were located randomly along the entire length of the shoreline, with the exception of the following excluded areas: small, shallow coves on the west side of the reservoir; the four dams; and $200 \mathrm{~m}$ on either side of each dam.

Along each transect, we estimated the percent cover of every species present in $1-\mathrm{m}^{2}$ plots in mid-September of 2001 and 2002. Plants were identified to species when possible using local and regional floras (Great Plains Flora Association 1986, Weber 1990). Plots were spaced variably depending on the steepness of the slope so that they were evenly distributed along the elevational gradient. On steep slopes, a plot was sampled every meter; on progressively gentler slopes, plots were sampled at intervals of 2,3 , or $4 \mathrm{~m}$ in order to achieve as close as practicable to 3 plots per $\mathrm{m}$ of elevation change. Transect lengths ranged from 89 to $382 \mathrm{~m}$. Following exclusion of plots without clear hydrologic history as described below, the numbers of plots analyzed per transect ranged from 80 to 142 with a total of 1,345 plots each year. The proportion of surface area at each plot that was occupied by cobblesized particles or larger $(>64 \mathrm{~mm}$ diameter) was estimated in the field. A single elevation of each plot was determined using a total station surveying instrument, registered to the water surface elevation and tied to the 
Fig. 1 Reservoir water surface elevation and drawdown zones. Vegetation analysis is limited to four distinct elevation zones: UPL was never inundated; MID was first exposed in 2000 and not subsequently; BTM was first exposed in 2000 and was subsequently re-flooded and re-exposed in both 2001 and 2002 TOP was first exposed in 1999 and not subsequently;

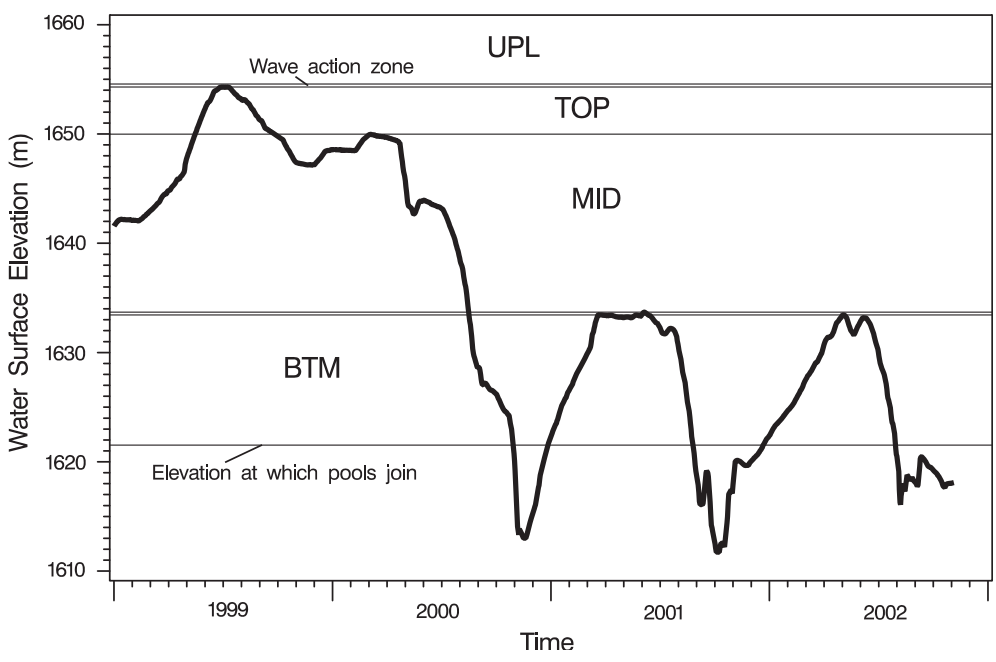

gage measuring long-term reservoir water levels. Substrate characteristics and topography were measured in 2001. General observations in 2002 suggested that there had been little change in substrate or topography between years.

Records of water level fluctuation during the study period were combined with plot elevations to estimate when plots were exposed. Using this information, we divided the transects into four basic zones (from highest elevation to lowest): UPL, an upland zone above the level of reservoir inundation; TOP, former reservoir bottom exposed during the 1999 growing season and not inundated again during the study; MID, former reservoir bottom exposed during the 2000 growing season and not inundated again during the study; and BTM, former reservoir bottom exposed temporarily during the 2000, 2001, and 2002 growing seasons (Figs. 1 and 2). Areas excluded from analysis consisted of (1) portions of transects below $1621.5 \mathrm{~m}$ asl where separate pools began to form in various portions of the reservoir; (2) a wave action zone, above the high water mark of the reservoir, but still disturbed; and (3) a narrow band between the MID and BTM zones that was exposed in 2000 and 2001 but was not re-exposed in 2002 . The wave action zone and the zone exposed only in 2000 and 2001 each spanned less than $0.5 \mathrm{~m}$ of the elevation gradient and had too few plots for meaningful analysis.

\section{Data Analysis}

\section{Plant characteristics and communities}

Plant characteristics are summarized by elevational zone and sampling year with each combination denoted by the zone (BTM, MID, TOP, and UPL) subscripted by the last two digits of the year of sampling

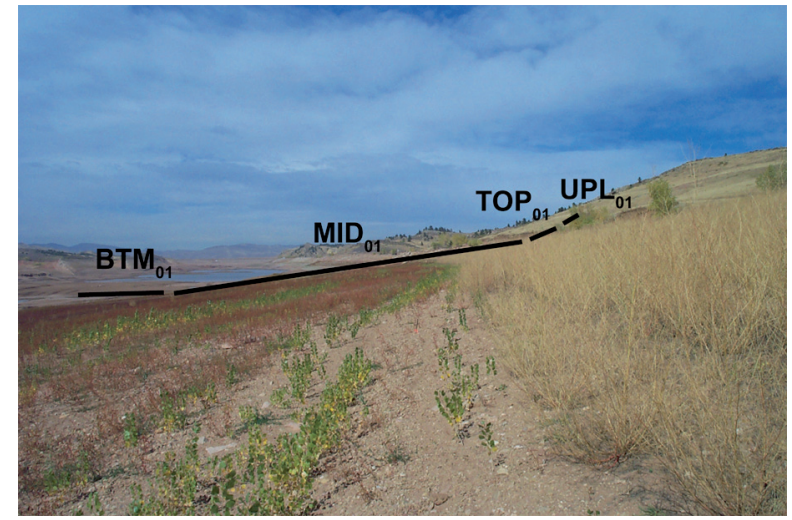

Fig. 2 Horsetooth Reservoir when sampled in September 2001. At this time, the $\mathrm{TOP}_{01}$ zone was in the third year of exposure, $\mathrm{MID}_{01}$ in the second year, and $\mathrm{BTM}_{01}$ in the first year. Secondyear seedlings of Populus deltoides subsp. monilifera are evident in the MID $_{01}$ zone and several mature individuals are present near the full pool elevation of the reservoir before drawdown. Melilotus spp. strongly dominates the $\mathrm{UPL}_{01}$ zone here

(2001 and 2002). The resulting eight zone-year combinations are grouped into classes based on the number of years since the zone was last exposed or drawn down (1, 2, 3, 4 years and Upland). There was no preexisting, rooted vegetation in any of these zones prior to their first exposure and no apparent survival of vegetation in the BTM zone between the two successive years it was drawn down.

Fractional nativity, duration, and wetland index were based on the aggregate species list for each zoneyear-transect combination. Nativity was calculated as the fraction of species classified as native and duration was calculated as the fraction of species classified as perennial based on McGregor et al. (1986) and USDANRCS (2004) For example, a value of 0.6 for nativity would mean $60 \%$ of the species were classified as native and a value of 0.4 for duration would mean $40 \%$ 
of the species were classified as purely perennial (as opposed to annual, biennial or with a mixed duration). Wetland indicators (Reed 1988, USDA-NRCS 2004) for individual plants of Obligate (OBL), Facultative Wetland (FACW), Facultative (FAC), Facultative Upland (FACU), and Upland (UPL) were assigned numeric values of 1 to 5, respectively (Tiner 1999). Thus, values of the wetland index range from 1.0 for a hydric community composed entirely of obligate wetland species to 5.0 for a xeric community composed entirely of upland species.

Total vegetative cover within each zone-year-transect combination was adjusted for differences in substrate by analysis of covariance using rockiness (proportion of surface occupied by cobble or larger particles) as a covariate. This analysis (Proc Mixed, SAS 2003) fit separate relationships between an arcsine square root transformation of cover and a square root transformation of rockiness for each zone-year combination. We report total vegetative cover means and $95 \%$ confidence intervals for each zone-year combination adjusted to the grand mean of the covariate.

Direct comparisons of observed species richness across zones and transects were not possible because of the different areas and numbers of plots sampled. We pooled all plots sampled in each zone-year combination, without regard to transect, in order to develop comparable estimates of species richness. We used two procedures. A first-order jackknife estimate of total richness is based on the number of observed species, the number of sampled plots, and the number of species observed in only one plot (McCune and Grace 2002). We also used a bootstrap procedure to estimate the total number of species as the asymptote of a fitted species-area curve. For each zone-year combination, we drew 50 random samples of each number of plots ( 1 to $n=$ total number of plots), averaged the total number of species for each number of plots, and then fit a curve to the data [Michaelis-Menten equation following Inouye (1998)].

Differences in dominant species were evaluated by calculating species cover relative to the total cover within each zone-year-transect combination. Differences in overall species composition between zoneyear combinations were evaluated using relative Sorensen distance (McCune and Meford 1999, McCune and Grace 2002) expressing a percent dissimilarity of the distribution of cover across species, normalized to the total cover within a zone-year combination. This index was based on cover values for each zone-year obtained by first averaging all plots within a zone-yeartransect and then averaging across transects within each zone-year combination.

\section{Cottonwood seedling establishment}

We examined a priori expectations derived from Mahoney and Rood's (1998) recruitment box model concerning (1) the position of new seedlings relative to the water's edge during the period of seed availability and (2) rates of water level decline that could be survived by new seedlings. For these analyses, we pooled plots across transects and years. We then calculated average cover of first-year Populus deltoides subsp. monilifera seedlings for each year in elevational zones relative to the elevations of the water surface each year during the seed release and germination window. We used the period of June 1 to July 7 for seed release and germination based on Segelquist et al. (1993) and our antecdotal observations in Fort Collins from 1990 to 2005. To examine the effects of drawdown rate, we focused on plots within the elevational zone corresponding to the location of the water's edge during the germination window. These plots were both predicted and observed to have the highest probabilities of establishment. For each of these plot-year combinations, we estimated the drawdown rate as the difference between the water surface elevation on the last day the plot was inundated and the water surface elevation 45 days later. In some cases, especially in 2002 when drawdown was very rapid, the water surface elevation 45 days later was below the limit of $1621.5 \mathrm{~m}$ asl at which pools formed in the reservoir bottom and reliable estimates of water surface at individual transects were not possible. In these cases, we used 1621.5 $\mathrm{m}$ asl as a lower bound of water surface elevation, thus producing a conservative (low) estimate of the rate of decline experienced by seedlings. Average cover of Populus deltoides subsp. monilifera seedlings was calculated for classes of drawdown rate by pooling observations of current year germinants in both 2001 and 2002.

\section{Results}

Plant Characteristics and Communities

The percentage of native species was relatively constant over time with median values ranging from $56 \%$ for $\mathrm{BTM}_{02}$ exposed for one year to $40 \%$ for $\mathrm{TOP}_{02}$ exposed for four years (Fig. 3). There was no suggestion of a trend for the early colonizing communities to be shifting towards the higher proportions of native species associated with the upland that had median percentages of native species of $75 \%$ and $71 \%$ in the two years of sampling. In contrast, both duration and 


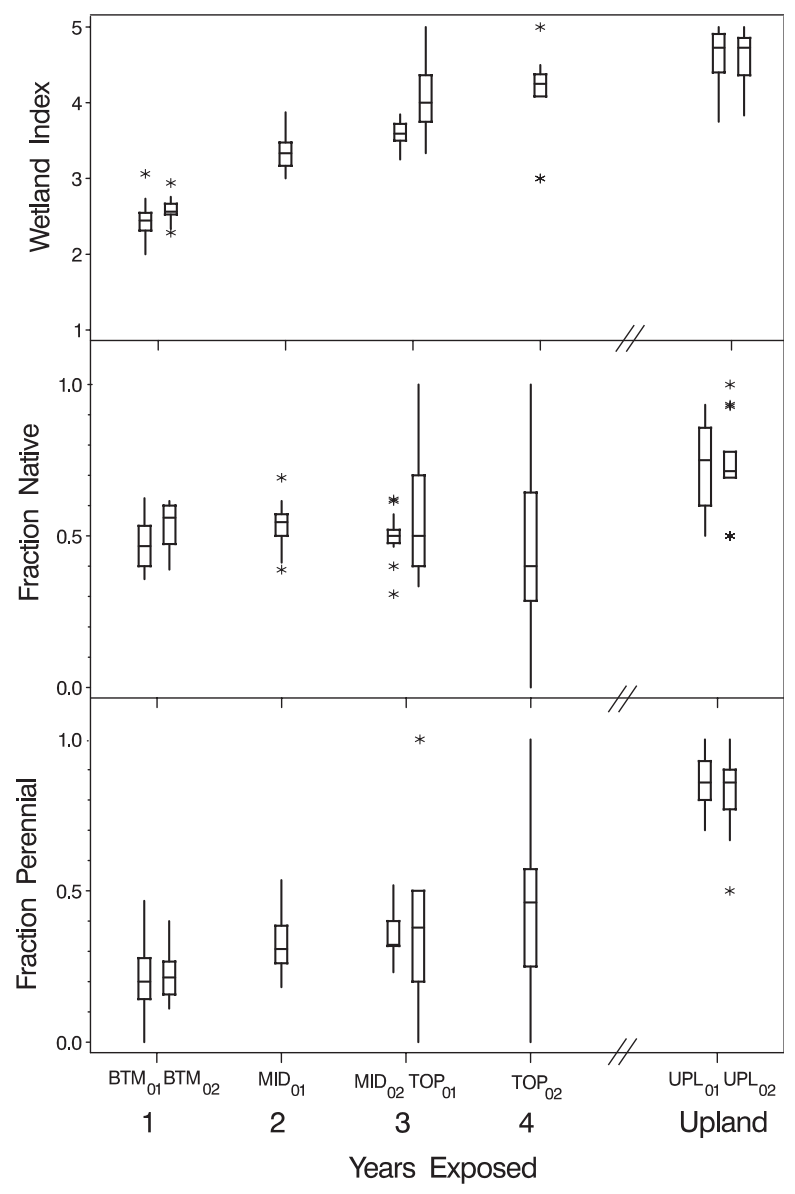

Fig. 3 Vegetation characteristics by drawdown zone and time exposed. The unit of replication is a transect within each zoneyear combination. Wetland index, fraction native, and fraction perennial are calculated for each plot based on species presence and then averaged across plots for each transect within a zoneyear combination. Tops and bottoms of boxes represent $75^{\text {th }}$ and $25^{\text {th }}$ percentiles, the horizontal line is the median, whiskers (vertical lines) include the minimum of 1.5 times the interquartile range and the range of the data, and values outside the whiskers are represented by asterisks

wetland index showed clear trends of increasing over the first four years of exposure toward values observed in the upland zone (Fig. 3). Median percentages of perennial species were $20 \%$ and $21 \%$ in the first year of exposure $\left(\mathrm{BTM}_{01}\right.$ and $\left.\mathrm{BTM}_{02}\right) ; 31 \%$ after two years $\left(\mathrm{MID}_{01}\right) ; 32 \%$ and $38 \%$ after three years $\left(\mathrm{MID}_{02}\right.$ and $\left.\mathrm{TOP}_{01}\right)$; and $46 \%$ after four years $\left(\mathrm{TOP}_{02}\right)$. The median percentage of perennial species in the upland zone was $86 \%$ in both 2001 and 2002. Median values for wetland index in the first year of exposure were 2.4 and $2.6\left(\mathrm{BTM}_{01}\right.$ and $\left.\mathrm{BTM}_{02}\right)$, which are in the range of wetland vegetation communities (Tiner 1999). Wetland index increased steadily over time to 4.2 in the fourth year $\left(\mathrm{TOP}_{02}\right)$ approaching the xeric value of 4.7 for both 2001 and 2002 in the upland zone (Fig. 3).

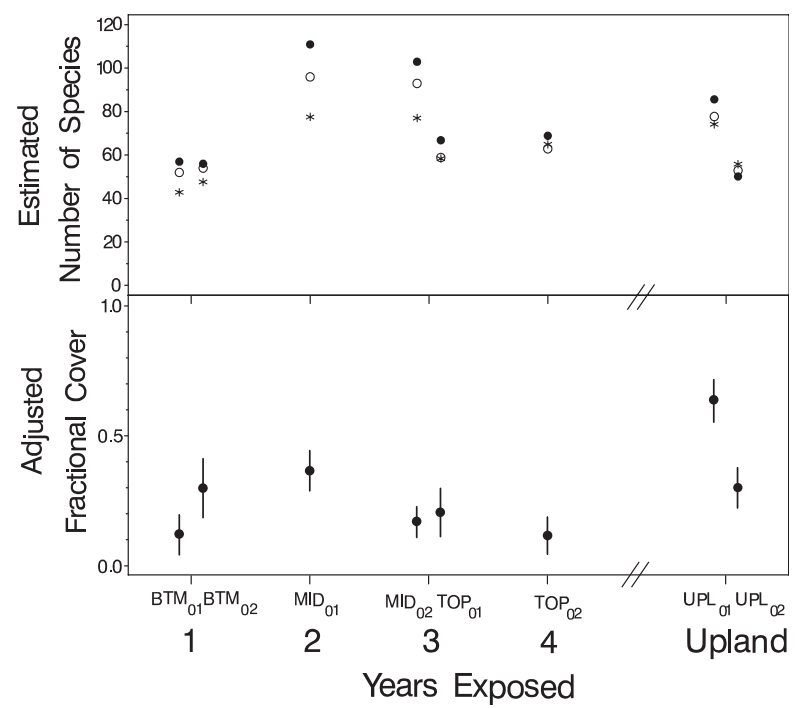

Fig. 4 Species richness and adjusted total cover by drawdown zone and time exposed. In the top graph, asterisks are the asymptotic richness from Michaelis-Menten species-area curves fit to bootstrapped sets of $1-\mathrm{m}^{2}$ plots pooled across transects (Inouye 1998); open circles are first-order jack-knife estimates of richness (McCune and Grace 2002). In the bottom graph, solid circles are estimates of mean total cover adjusted to the grand mean substrate value from an analysis of covariance using transect within a zone-year combination as the unit of replication. The vertical lines from the solid circles are $95 \%$ confidence intervals for these estimated means

Patterns in both species richness and cover were complicated by differences among sampling years in precipitation and among zones in substrate and sampled area. The second year of sampling, 2002, was drier than 2001, which contributed to lower total 2002 cover in the upland zone and lower numbers of identifiable species.

We recorded a total of 124 distinct taxa. In some cases these were combinations of species that could not be reliably separated in the field at the time of sampling. Examples among the more dominant species include conflation of Bromis japonicus and B. tectorum, and Melilotus spp. which included Melilotus alba and M. officinalis. Differences in estimation procedures for total species richness did not appreciably change the relative patterns (Fig. 4). Based on the first-order jackknife estimate, species richness was 52 and 53 species in the first year following exposure $\left(\mathrm{BTM}_{01}\right.$ and $\left.\mathrm{BTM}_{02}\right)$ compared to 78 and 53 species in the upland zone (UPL $\mathrm{UL}_{01}$ and $\mathrm{UPL}_{02}$ ). There was some suggestion of an intermediate peak in richness in the second ( 96 for MID $_{01}$ ) and third ( 93 for $\mathrm{MID}_{02}$ and 59 for $\mathrm{TOP}_{01}$ ) years of exposure.

The substrate area composed of large particles $(>64$ $\mathrm{mm}$ diameter) was a significant predictor of total cover $(P<0.001)$, with more rocky substrate associated with 
Table 1 Community dissimilarity matrix. Distance measure is a Sorensen percent dissimilarity using mean cover values for each zoneyear combination and relativized to zone-year unit totals (McCune and Grace 2002). Values range from $0 \%$ for identical species cover composition to $100 \%$ for no similarity of species cover composition. Matrix is symmetrical around main diagonal. Main diagonal entries are indicated by dashes and are 0 by definintion

\begin{tabular}{|c|c|c|c|c|c|c|c|c|c|}
\hline \multirow[b]{4}{*}{ Years exposed } & \multirow[b]{4}{*}{ Zone year } & \multicolumn{8}{|c|}{ Relativized Sorenson distance (\% dissimilarity) } \\
\hline & & \multicolumn{8}{|c|}{ Years exposed } \\
\hline & & \multicolumn{2}{|c|}{1} & \multirow{2}{*}{$\frac{2}{\mathrm{MID}_{01}}$} & \multicolumn{2}{|c|}{3} & \multirow{2}{*}{$\frac{4}{\mathrm{TOP}_{02}}$} & \multicolumn{2}{|c|}{ Upland } \\
\hline & & BTM $_{01}$ & $\mathrm{BTM}_{02}$ & & $\mathrm{MID}_{02}$ & $\mathrm{TOP}_{01}$ & & $\mathrm{UPL}_{01}$ & $\mathrm{UPL}_{02}$ \\
\hline \multirow[t]{2}{*}{1} & $\mathrm{BTM}_{01}$ & - & 15 & 58 & 80 & 87 & 94 & 99 & 99 \\
\hline & $\mathrm{BTM}_{02}$ & 15 & - & 65 & 79 & 88 & 94 & 99 & 99 \\
\hline 2 & $\mathrm{MID}_{01}$ & 58 & 65 & - & 51 & 58 & 79 & 98 & 98 \\
\hline \multirow[t]{2}{*}{3} & $\mathrm{MID}_{02}$ & 80 & 79 & 51 & - & 58 & 79 & 98 & 97 \\
\hline & $\mathrm{TOP}_{01}$ & 87 & 88 & 58 & 58 & - & 50 & 91 & 92 \\
\hline 4 & $\mathrm{TOP}_{02}$ & 94 & 94 & 79 & 54 & 50 & - & 84 & 83 \\
\hline \multirow[t]{2}{*}{ Upland } & $\mathrm{UPL}_{01}$ & 99 & 99 & 98 & 97 & 91 & 84 & - & 19 \\
\hline & $\mathrm{UPL}_{02}$ & 99 & 99 & 98 & 97 & 92 & 83 & 19 & - \\
\hline
\end{tabular}

lower total cover (Fig. 4). Total plant cover, adjusted with analysis of covariance to the mean fraction of large particles, was $21-36 \%$ in the first year of exposure $\left(\mathrm{BTM}_{01}\right.$ and $\left.\mathrm{BTM}_{02}\right)$. There was some suggestion of a decline in cover within the first four years of exposure, rather than a trend in the direction of the generally higher (37-58\%) upland cover values.

Species composition was most similar between zoneyear combinations within a given time of exposure (Table 1). Species composition of exposed areas became progressively more similar to the upland composition with increasing time of exposure. Composition at one year of exposure was $99 \%$ dissimilar to the uplands, and composition at four years of exposure was $83-84 \%$ dissimilar to the uplands. There was, however, substantial turnover of species within the first four years, with generally large dissimilarities between the different years (e.g., 94\% dissimilarity between one and four years exposed).

There were also substantial shifts in the individual dominant species related to time exposed (Table 2). The introduced annual Chenopodium glaucum, with a FACW wetland indicator value, strongly dominated the first-year communities, was the second most dominant species two years after exposure, but was strongly reduced in the third year and absent from fourth-year and upland zones. Panicum capillare, a native annual, was the second most dominant species in the first year of exposure, increased to the most dominant species in the second year, declined in the third and fourth years, and was absent from the upland zone. The native Rorippa curvipes is classified as an obligate (OBL) wetland plant and was important in the first year of exposure, declined to a very minor presence in the second year, and was absent in the third-year, fourthyear, and upland communities.

Some of the dominant species in the second through fourth years of exposure were substantially less important or absent from both the first year of exposure zone and the upland zone. These included Cirsium arvense, Ericameria nauseosa, Lactuca serriola, Salsola collina, Verbascum thapsus, and Verbena bracteata. The conflated Bromus japonicus and B. tectorum, both introduced, dominated the upland zone. This group was absent in the first year of exposure and gradually increased in relative cover in the second through fourth years. The other most dominant species in the upland, Bromus inermis, Cercocarpus montanus, and Rhus aromatica, were unimportant or absent in essentially all of the first four years of exposure (Table 2).

\section{Cottonwood Seedling Establishment}

Plains cottonwood (Populus deltoides subsp. monilifera) was the dominant tree species colonizing the exposed surfaces (Table 2). Mature individuals occurred in the upland near the margin of the full-pool reservoir, although none were sampled in the upland plots on randomly located transects. Seedlings of Salix amygdaloides, S. exigua, Populus angustifolia, $P$. tremuloides, and Tamarix ramossima were present, but rare in the drawdown zones along sampled transects. First-year cottonwood (Populus deltoides subsp. monilifera) seedlings were generally distinguishable from previous year germinants and root sprouts by their cotyledons and absence of bud scale scars when 
Table 2 Relative cover of selected species by elevational zone and time exposed. Relative cover is calculated at the transect level for each zone-year combination and then averaged across transects. All species with cover ranks among the top four in any zone-year combination are included. Dashes indicate absence

\begin{tabular}{|c|c|c|c|c|c|c|c|c|c|c|c|}
\hline \multirow[b]{3}{*}{ Species } & \multicolumn{3}{|c|}{ Characteristics } & \multicolumn{8}{|c|}{ Relative Cover (\%) by Years Exposed and Sampled Zone } \\
\hline & \multirow[b]{2}{*}{ Duration } & \multirow[b]{2}{*}{ Nativity } & \multirow{2}{*}{$\begin{array}{l}\text { Wetland } \\
\text { indicator }\end{array}$} & \multicolumn{2}{|c|}{1} & \multirow{2}{*}{$\frac{2}{\mathrm{MID}_{01}}$} & \multicolumn{2}{|c|}{3} & \multirow{2}{*}{$\frac{4}{\mathrm{TOP}_{02}}$} & \multicolumn{2}{|c|}{ Upland } \\
\hline & & & & $\mathrm{BTM}_{01}$ & $\mathrm{BTM}_{02}$ & & $\mathrm{MID}_{02}$ & $\mathrm{TOP}_{01}$ & & $\mathrm{UPL}_{01}$ & $\mathrm{UPL}_{02}$ \\
\hline Amaranthus albus & A & $\mathrm{N}$ & FACU & 2.2 & 7.1 & 3.7 & 2.6 & - & - & - & - \\
\hline Ambrosia tomentosa & $\mathrm{P}$ & $\mathrm{N}$ & UPL & $<0.1$ & $<0.1$ & 4.6 & 9.3 & - & - & - & - \\
\hline Bromus inermis & $\mathrm{P}$ & $\mathrm{E}$ & UPL & - & $<0.1$ & $<0.1$ & $<0.1$ & - & 0.3 & 13.0 & 11.0 \\
\hline Bromus japonicus - B. tectorum & A & $\mathrm{E}$ & UPL & - & - & $<0.1$ & 0.2 & 1.7 & 4.3 & 24.7 & 18.7 \\
\hline Cercocarpus montanus & $\mathrm{P}$ & $\mathrm{N}$ & UPL & - & - & - & - & 0.6 & 2.3 & 10.4 & 17.1 \\
\hline Chenopodium glaucum & A & $\mathrm{E}$ & FACW & 57.8 & 56.1 & 15.8 & 0.4 & - & - & - & - \\
\hline Cirsium arvense & $\mathrm{P}$ & $\mathrm{E}$ & FACU & 0.2 & 0.1 & 1.8 & 13.3 & 0.8 & 3.5 & 1.0 & 0.7 \\
\hline Ericameria nauseosa & $\mathrm{P}$ & $\mathrm{N}$ & UPL & - & - & $<0.1$ & 0.2 & 10.3 & 9.2 & 1.7 & 1.8 \\
\hline Lactuca serriola & A & $\mathrm{E}$ & FAC & - & - & 2.0 & 2.9 & 12.0 & 11.7 & - & - \\
\hline Melilotus spp. & $\mathrm{A} / \mathrm{B}$ & $\mathrm{E}$ & FACU & 0.2 & 0.1 & 9.5 & 5.9 & 15.1 & 0.7 & 0.5 & - \\
\hline Panicum capillare & A & $\mathrm{N}$ & FAC & 10.4 & 10.3 & 26.2 & 7.2 & 8.0 & 1.2 & - & - \\
\hline $\begin{array}{l}\text { Populus deltoides subsp. } \\
\text { monilifera }\end{array}$ & $\mathrm{P}$ & $\mathrm{N}$ & FAC & 4.4 & 1.8 & 2.4 & 3.5 & 0.4 & 0.5 & - & - \\
\hline Rhus aromatica & $\mathrm{P}$ & $\mathrm{N}$ & UPL & - & - & - & - & - & - & 13.2 & 9.2 \\
\hline Rorippa curvipes & $\mathrm{A} / \mathrm{B} / \mathrm{P}$ & $\mathrm{E}$ & FACW & 5.3 & 0.9 & $<0.1$ & - & - & - & - & \\
\hline Salsola collina & A & $\mathrm{E}$ & UPL & - & - & 0.9 & 15.1 & 2.9 & 13.3 & - & 0.3 \\
\hline Suckleya suckleyana & A & $\mathrm{N}$ & FACW & 3.5 & 7.2 & 0.1 & 0.2 & - & - & - & - \\
\hline Verbascum thapsus & B & $\mathrm{E}$ & UPL & $<0.1$ & $<0.1$ & 1.3 & 2.5 & 11.1 & 11.7 & - & - \\
\hline Verbena bracteata & $\mathrm{A} / \mathrm{P}$ & $\mathrm{N}$ & UPL & 0.2 & 0.2 & 9.6 & 10.3 & 9.9 & 4.0 & $<0.1$ & - \\
\hline
\end{tabular}

$\mathrm{A}=$ annual, $\mathrm{B}=$ biennial, $\mathrm{P}=$ perennial, $\mathrm{N}$ = native, $\mathrm{E}=$ exotic, $\mathrm{W}=$ wetland, FACW $=$ facultative wetland, $\mathrm{FAC}=$ facultative, $\mathrm{FACU}$ $=$ facultative upland, UPL $=$ upland

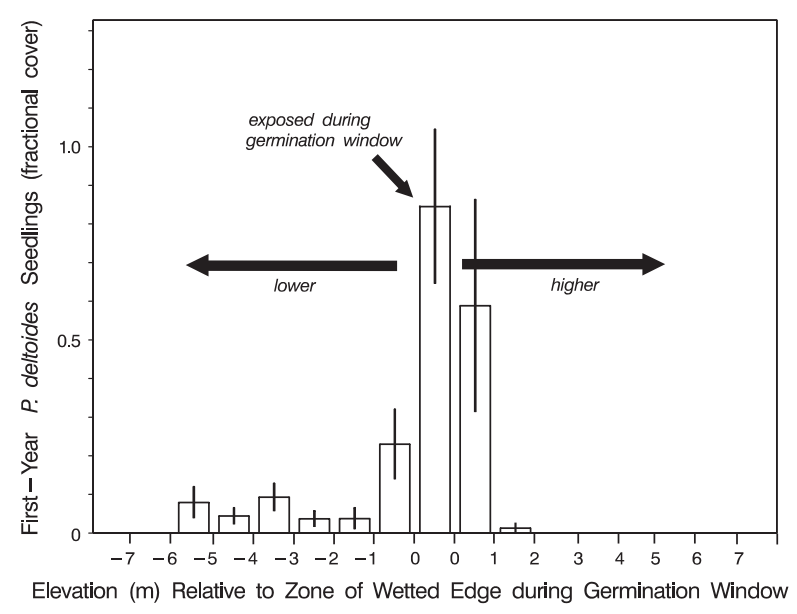

Fig. 5 Elevational distribution of first-year Populus deltoides subsp. monilifera seedlings in relation to the elevations exposed during the germination window of June 1 to July 7. Means \pm 1 SE are based on plots in each elevational class pooled across transects and sampling years

sampled in mid-September. New seedlings were strongly concentrated in, or slightly above, the elevational band occupied by the water's edge during the period of seed release of June1 to July 7 (Fig. 5). However, smaller numbers of new seedlings were spread over a considerable range of elevations from $2 \mathrm{~m}$

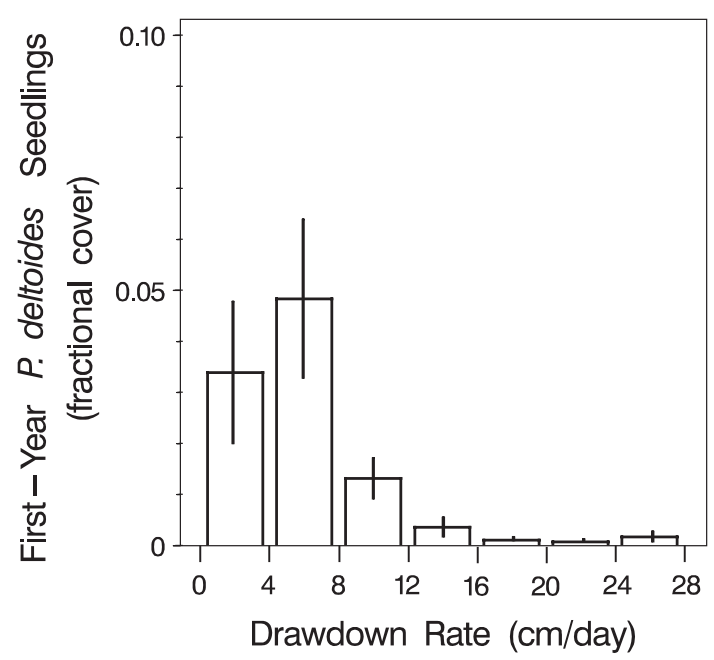

Fig. 6 Cover of first-year Populus deltoides subsp. monilifera seedlings (established in the zone of the wetted edge during the germination window) in relation to rate of drawdown. Means $\pm 1 \mathrm{SE}$ are based on plots in each drawdown class pooled across transects and sampling years. Drawdown is calculated for the 45-day period following the date a plot was last exposed

above the zone exposed during the germination window to more than $5 \mathrm{~m}$ below the optimum zone. Drawdown rate had a strong influence on the cover of first-year seedlings as sampled near the end of the growing season 
(Fig. 6). For seedlings established in the optimum band of the wetted edge during the germination window, cover decreased substantially at drawdown rates greater than 4-8 cm/day. However, the range of drawdown rates survived by seedlings was wide, with new seedlings present with measurable cover at rates of greater than $24 \mathrm{~cm} /$ day. The zone of maximum cover of current year germinants was 10.2 to $12.2 \mathrm{~m}$ above the water level on September 1 in 2001 and 7.2-11.7 m above in 2002, using the conservative $1621.5 \mathrm{~m}$ asl elevation at which separate pools formed in the reservoir. Actual observed water levels at the dam on September 1 were $1618.8 \mathrm{~m}$ asl in 2001 and $1618.1 \mathrm{~m}$ asl in 2002 . Average elevations of all plots containing older than first-year Populus deltoides subsp. monilifera seedlings in 2001 were $9.6 \mathrm{~m}$ above the maximum water level in that year and $21.8 \mathrm{~m}$ above the conservative $1621.5 \mathrm{~m}$ asl value for September 1 water level; in 2002, older seedlings were $7.5 \mathrm{~m}$ above the maximum and $19.5 \mathrm{~m}$ above the conservative September 1 level.

\section{Discussion}

Nilsson et al. (1997) distinguished land as pre-upland or pre-riparian in an analysis of vegetation response to inundation from dam construction. This distinction is similarly useful in describing the response of vegetation to dam removal. Large fractions of the land under the reservoir pools of the shallow dam removal sites in Wisconsin examined by Orr and Stanley (2006) and Lenhart (2000) were pre-riparian. Contingent on changes in topography from sediment accumulated behind the dam and the geomorphic response to dam removal, pre-riparian areas might be expected to support marshland or riparian vegetation following dam removal (Shafroth et al. 2002).

In contrast, we sampled slightly more than 30 meters of drawdown at Horsetooth Reservoir. Essentially all of the area exposed was pre-upland. If this had been a permanent dam removal, the exposed area would not be expected to support a wetland or riparian plant community in the long term. The patterns of vegetation change we observed are a combination of the initial colonization of a riparian, bare ground disturbance patch and the vegetation response to a shift from mesic to xeric site conditions. The mesic to xeric transition is reflected in the wetland index value, which systematically increased from a hydric or wetland community in the first year of exposure to upland or xeric value in the fourth year of exposure, very similar to the upland values of the surrounding landscape vegetation. In contrast, Len- hart (2000) reported wetland index values at sites 3-5 years following removal of shallow dams in Wisconsin that were still indicative of hydric or wetland communities. The species composition at the Horsetooth site changed dramatically over the first four years of exposure (Tables 1 and 2), but had not yet approached that of the surrounding upland plots.

The initial colonizing community of a bare surface might be expected to have higher fractions of shortlived and perhaps non-native species than later vegetation on the site. At the Horsetooth site, the fraction of perennials steadily increased through four years of exposure, whereas the fraction of native species was below that of the surrounding uplands and did not change appreciably or consistently. Substrate-adjusted mean values for total cover were lower than the upland and appeared to decline somewhat in the second through fourth years of exposure. A possible explanation for these patterns in cover and richness is that the mesic conditions in the first year of exposure produce a reasonably high plant cover composed heavily of annual species. This is followed by a period of reorganization, replacing annuals with deeper rooted perennials. Species richness peaks during this transition, whereas total cover tends to drop in the drier conditions of years two through four following exposure and only gradually increases to the ultimately higher cover of a slowly developing perennial community present on the dry upland sites.

The cottonwood recruitment box model of Mahoney and Rood (1998) expresses the regeneration niche of these disturbance-dependent, pioneer, riparian tree species and makes predictions about where recruitment will occur along rivers in central and western North America in relation to water surface elevations (Rood et al. 2005). Cottonwood seedling establishment requirements are well known from multiple laboratory (Fenner et al. 1984, Mahoney and Rood 1991, Segelquist et al. 1993, Amlin and Rood 2002) and field studies (Rood et al. 1998, Auble and Scott 1998, Shafroth et al. 1998, Rood and Mahoney 2000, Rood et al. 2005). Seedling recruitment tends to occur on bare ground sites that are moist during an early summer period of seed dispersal and germinability, and that remain moist enough for seedlings to survive drought stress. More specifically, for Populus deltoides subsp. monilifera, the model describes suitable establishment sites as (1) bare ground, largely created by fluvial disturbance; (2) wetted by water surface elevations during a 3- to 6-week window of seed release, dispersal, and germinability; (3) subject to water table declines of no more than $2.5 \mathrm{~cm} /$ day; and (4) generally occurring at elevations from 60 to 
$200 \mathrm{~cm}$ above the water surface elevation of late summer base flow (Mahoney and Rood 1998).

The Horsetooth drawdown provided bare, wetted surfaces over a much greater elevational range than would be associated with riparian floodplain sites or removal of a shallow dam. Predictions of the recruitment box model were met in two respects. First, the highest cover of first-year $P$. deltoides subsp. monilifera occurred in the elevation zone corresponding to the water's edge during the estimated June 1 to July 7 period of estimated maximum seed release and germinability for the area (Fig. 5). Second, cover of firstyear seedlings dropped sharply at locations subject to drawdown rates $>8 \mathrm{~cm} /$ day (Fig. 6). However, there was appreciable seedling establishment well outside the bounds predicted by the recruitment box model. Wave action, capillary rise, and plot heterogeneity in elevation are likely explanations for the substantial establishment in locations $0-1 \mathrm{~m}$ above the water's edge. The establishment at much lower elevations as far as 5-6 m below the water's edge on July 7 is more difficult to explain. It appears that the extreme drawdown rates created suitable bare moist sites far below the elevation of the optimum, but close enough to the period of maximum seed availability to allow some of the tail end of the distribution of germinable seed to establish.

We observed maximum cover at drawdown rates of 4-8 $\mathrm{cm} /$ day compared to the upper limit of $2.5 \mathrm{~cm} /$ day used in the recruitment box model, and we observed some seedlings surviving first-year drawdown rates of greater than $24 \mathrm{~cm} /$ day. Some survival of seedlings at drawdown rates of 4 and $8 \mathrm{~cm} /$ day has been reported in laboratory experiments (Mahoney and Rood 1991) and the value of $2.5 \mathrm{~cm} /$ day is probably better viewed as the upper end of the most suitable range of rates rather than as an absolute limit. The rapid Horsetooth drawdown rates produced seedling establishment at high elevations relative to late summer water levels. The elevation zone with maximum cover of first-year seedlings was at least $10 \mathrm{~m}$ above the water level on September 1 in 2001 and at least $7 \mathrm{~m}$ above the September 1 level in 2002. This was not purely a first-year phenomenon as the average elevations of older than currentyear seedlings were well above the range of current year water levels, more than $7 \mathrm{~m}$ above the maximum level of the current year and more than $19 \mathrm{~m}$ above the level on September 1 of the current year. Mahoney and Rood (1998) discuss several factors that may support establishment at high elevations relative to the water's edge including capillary rise, lateral subsurface water movement, and advantageous sequences of precipitation events. Given that some exposed surfaces at
Horsetooth Reservoir were on the sides of sharp ridges with very limited contributing drainage area, we believe the most likely explanation for the high elevation establishment we observed is local variation in particle size and subsurface drainage (i.e., fine sediment in cracks between boulders) that create pockets of adequate moisture retained from inundation and channeled from rainwater-derived percolation.

\section{Implications for Dam Removal Decisions}

Given the multiple dimensions in which dams differ (Poff and Hart 2002) and the relative paucity of longterm dam removal data sets, evaluations and decisions about dam removal in the near future will be based largely on case studies and site assessments rather than on statistical conclusions from a sampled population of previous removals. A first-order approximation of future vegetation within a former reservoir pool can be obtained by considering topography of the new surface in relation to the new water surfaces; substrate characteristics; the pre-dam vegetation and its character as pre-upland or pre-riparian; and typical wetland, riparian, and upland vegetation communities in the region (Shafroth et al. 2002). For shallow dams constituting the vast majority of dams removed to date (Hart and Poff 2002), the exposed surfaces will be at elevations close to the surface of the new river and a large fraction of the exposed area would have been riparian or wetland before inundation. For tall dams and the drawdown case we report, the vast majority of the exposed land is preupland, not significantly influenced by a river before dam construction, substantially above the water surface following removal or exposure, and likely to support upland vegetation typical of the region.

There are two primary ways such a first approximation could be misleading. The first is that the postdam topography and substrate characteristics may have been altered substantially by the period of inundation. This is especially true if the dam has accumulated substantial quantities of trapped sediment that have altered topography, stored nutrients or contaminants, or altered organic content or particle size distributions. Our results showed a significant effect of substrate size proportions on total vegetation cover; however, Horsetooth Reservoir was not accumulating substantial sediment because of the diversion source of most of the impounded water.

The second way a first approximation might be misleading is that the character of the transition between extended inundation to post-dam site conditions will influence vegetation response over some time scale, at least on the order of the life spans of 
the initially colonizing plants. Erosion of accumulated sediment may produce substantial changes in postdam topography, likely resulting in a topography intermediate between the pre-dam and immediately exposed conditions. This was not a major factor at Horsetooth Reservoir because of the relative absence of accumulated sediment. On the other hand, extended inundation is an abnormal source of disturbance to initiate a bare ground plant succession for pre-upland surfaces such as those exposed by the Horsetooth Reservoir. Thus, the initially colonizing plant community was considerably more mesic (lower wetland indicator score) than the community that might colonize a dry, bare-ground surface created by a disturbance such as fire. In semi-arid landscapes, establishment of pioneer riparian tree species such as $P$. deltoides subsp. monilifera is almost always associated with hydrologic disturbance and bare ground sites near the water's edge, although mature trees can often persist on much drier sites. Thus, successful establishment of riparian cottonwood during the drawdown may leave a transient legacy of vegetation on the exposed reservoir surfaces that would be atypical of the sites either before reservoir construction or over the long term following dam removal. These patterns are very much a function of the specifics of reservoir drawdown and are thus potentially amenable to management as part of a dam removal. For example, cottonwood would be unlikely to colonize the bulk of pre-upland first-year exposure sites if the drawdown occurred in winter and the area was dry during the early summer period of seed release. On the other hand, the summer drawdowns observed at Horsetooth probably increased total plant cover on the exposed surfaces, which might be desirable from the perspective of erosion mitigation.

Weed control on the former reservoir pool is a consideration in many dam removal evaluations. Initial colonization of the reservoir pools at Horsetooth was by a ruderal community (Menges and Waller 1983, Grime 2001) with high fractions of short-lived species, including invasive, non-native weeds. This is a reasonable expectation of a riparian bare ground disturbance patch and generally for reservoir pool surfaces that might be exposed by dam removal where nonnative species are common in the regional species pool (e.g., Orr and Stanley 2006, Lenhart 2000). Effective weed control is complicated in the case of a tall dam. We observed a dramatic turnover of dominant species during the first four years and substantial changes in wetland character of the vegetation in response to drier site conditions. This suggests that (1) species-focused weed control will have to be maintained over multiple years with shifting targets as some of the weeds are diminishing naturally and being replaced by other species; and (2) planting of a desired or transition crop to preempt space and resources from invading weeds will have to consider rapidly changing site conditions to be effective in both the initial drawdown and immediately subsequent years.

Stanley and Doyle (2003) suggested that dam removal is best viewed as a new disturbance with a consequent set of positive and negative effects, rather than a simple reversal of the original impacts of dam construction. Sediment transport is one clear example of hysteresis, where the pulse release of accumulated sediment can produce a post-removal response that is not a simple mirror image or reversal of the response to dam construction. Vegetation of the former reservoir pool is another such asymmetrical response. The existing plant community is eliminated quickly (weeks to months) following inundation of the reservoir pool from dam construction. Recovery follows a different path on a different time scale. Lenhart (2000) suggested that the initial establishment of stinging nettle (Utrica dioica) and rice-cut grass (Leersia oryzoides) on sediment of the former reservoir pool may be suppressing the development of woody vegetation on shallow dam removal sites in Wisconsin. We saw little indication of this type of effect, as the dominant species continued to shift rapidly in the first four years of the Horsetooth Reservoir drawdown. However, the changes we observed in the first four years suggest that recovery of the vegetation community will be on the time scale of years to decades. Vegetative cover, composition of dominant species, and proportions of native and perennial species were still changing after four years and were substantially different from the upland community representing the likely long-term vegetation. Furthermore, the establishment and survival of cottonwood in the drawdown zone suggests that the particular nature of the transition from decades of continuous inundation to a xeric condition may leave a legacy signature in the vegetation community at least on the decades to century time scale corresponding to the lifespan of cottonwood.

Acknowledgments The study was funded by the U.S. Geological Survey. B. Boaz, U.S. Bureau of Reclamation, provided reservoir water level data and logistical support. M. Caughlan (Larimer County), D. Fletcher (Lory State Park), and the Northern Colorado Water Conservancy District provided access to sites. J. Fleming, J. Knudson, and T. Sweanor assisted with field data collection and data management. The manuscript was improved substantially by comments from S. Rathburn, Z. Bowen, B. Keeland, S. Rood, and an anonymous reviewer. 


\section{References}

Amlin NM, Rood SB (2002) Comparative tolerances of riparian willows and cottonwoods to water-table decline. Wetlands 22:338-346

Auble GT, Scott ML (1998) Fluvial disturbance patches and cottonwood recruitment along the upper Missouri River, Montana. Wetlands 18:546-556

Bednarek AT (2001) Undamming rivers: a review of the ecological impacts of dam removal. Environmental Management 27:803-814

Beyer PJ (2002) Dialogue on dam removal: introduction. Journal of the American Water Resources Association 38:1509-1510

Fenneman NM (1931) Physiography of western United States. McGraw-Hill, New York

Fenner P, Brady WW, Patten DR (1984) Observations on seeds and seedlings of Fremont cottonwood. Journal of Desert Plants 6:55-58

Friedman JM, Osterkamp WR, Lewis WM, Jr 1996 Channel narrowing and vegetation development following a Great Plains flood. Ecology:2167-2181

Graf WL (ed.) 2003 Dam removal research: status and prospects. The Heinz Center, Washington, D.C

Great Plains Flora Association (1986) Flora of the Great Plains. University Press of Kansas, Lawrence

Grime JP (2001) Plant strategies, vegetation processes, and ecosystem properties. John Wiley and Sons, West Sussex, England

Hansen HC, Dahl E (1957) Some grassland communities in the mountain front zone in northern Colorado. Vegetatio 7:249_ 270

Hansen WR, Chronic J, Matelock J (1978) Climatography of the front range urban corridor and vicinity, Colorado. U.S. Geological Survey Professional Paper 1019. U.S. Government Printing Office, Washington, D.C

Hart DD, Poff NL (2002) A special section on dam removal and riparian restoration. Bioscience 52:653-655

Hart DD, Johnson TE, Bushaw-Newton KL, Horwitz RJ, Bednarek AT, Charles DF, Kreeger DA, Velinsky DJ (2002) Dam removal: challenges and opportunities for ecological research and river restoration. BioScience 52:669-681

Hill NM, Keddy PA, Wisheu IC (1998) A hydrological model for predicting the effects of dams on the shoreline vegetation of lakes and reservoirs. Environmental Management 22:723736

Inouye RS (1998) Species-area curves and estimates of total species richness in an old-field chronosequence. Plant Ecology 137:31-40

Keddy PA, Reznicek AA (1982) The role of seed banks in the persistence of Ontario's coastal plain flora. American Journal of Botany 69:13-22

Keddy PA, Reznicek AA (1986) Great Lakes vegetation dynamics: the role of fluctuating water levels and buried seeds. Journal of Great Lakes Research 12:25-36

Kondolf GM (1997) Hungry water: effects of dams and gravel mining on river channels. Environmental Management 21:533-551

Lenhart CF (2000) The vegetation and hydrology of impoundments after dam removal in southern Wisconsin. Ms. Thesis, Department of Landscape Architecture, University of Wisconsin, Madison

Lenhart CF (2003) A preliminary review of NOAA's community-based dam removal and fish passage projects. Coastal Management 31:79-89
Mahoney JM, Rood SB (1991) A device for studying the influence of declining water table on poplar growth and survival. Tree Physiology 8:305-314

Mahoney JM, Rood SB (1998) Streamflow requirements for cottonwood seedling recruitment: An integrative model. Wetlands 18:634-645

Marr JW (1961) Ecosystems of the east slope of the Front Range in Colorado. University of Colorado Studies, Series in Biology Number 8. University of Colorado Press, Boulder, Colorado

McCune B, Grace JB (2002) Analysis of ecological communities. MJM Software Design, Gleneden Beach, Oregon

McCune B, Medford MJ (1999) Multivariate Analysis of Ecological Data, Version 4.27. MjM Software, Gleneden Beach, Oregon

McGregor RL, Barkley TM, Brooks RE, Schofield EK (1986) Flora of the Great Plains. University Press of Kansas, Lawrence

Menges ES, Waller DM (1983) Plant strategies in relation to elevation and light in floodplain herbs. American Naturalist 122:454-473

Nilsson C, Keddy PA (1988) Predictability of change in shoreline vegetation in a hydroelectric reservoir, northern Sweden. Canadian Journal of Fisheries and Aquatic Science 45:18961904

Nilsson C, Jansson R, Zinko U (1997) Long-term responses of river-margin vegetation to water-level regulation. Science 276:798-800

Nilsson C, Reidy CA, Dynesius M, Revenga C (2005) Fragmentation and flow regulation of the world's large river systems. Science 308:405-408

Orr CH, Stanley EH (2006) Vegetation development and restoration potential of drained reservoirs following dam removal in Wisconsin. River Research and Applications 22:281-295

Peet RK (1981) Forest vegetation of the northern Colorado Front Range: Composition and dynamics. Vegetatio 45:3-75

Poff NL, Allan JD, Bain MB, Karr JR, Prestegaard KL, Richter BD, Sparks RE, Stromberg JC (1997) The natural flow regime. Bioscience 47:769-784

Poff NL, Hart DD (2002) How dams vary and why it matters for the emerging science of dam removal. Bioscience 52:659 668

Pohl MM (2002) Bringing down our dams: trends in American dam removal rationales. Journal of the American Water Resources Association 38:1511-1519

Reed PB (1988) National list of plant species that occur in wetlands: national summary. U.S. Department of the Interior, Fish and Wildlife Service Biological Report 88(24). Washington, D.C

Rood SB, Mahoney JM (2000) Revised instream flow regulation enables cottonwood recruitment along the St. Mary River, Alberta, Canada. Rivers 7:109-125

Rood SB, Kalischuk AR, Mahoney JM (1998) Initial cottonwood seedling recruitment following the flood of the century of the Oldman River, Alberta, Canada. Wetlands 18:557-570

Rood SB, Samuelson GM, Braatne JH, Gourley CR, Hughes FMR, Mahoney JM (2005) Managing river flows to restore floodplain forests. Frontiers in Ecology and the Environment 3:193-201

SAS (2003) SAS for Windows, Version 9.1. SAS Institute, Cary, North Carolina

Segelquist CA, Scott ML, Auble GT (1993) Establishment of Populus deltoides under simulated alluvial groundwater declines. American Midland Naturalist 130:274-285 
Shafroth PB, Auble GT, Stromberg JC, Patten DT (1998) Establishment of woody riparian vegetation in relation to annual patterns of streamflow, Bill Williams River, Arizona. Wetlands 18:577-590

Shafroth PB, Friedman JM, Auble GT, Scott ML, Braatne JH (2002) Potential responses of riparian vegetation to dam removal. BioScience 52:703-712

Stanley EH, Doyle MW (2002) A geomorphic perspective on nutrient retention following dam removal. Bioscience 52:693-702

Stanley EH, Doyle MW (2003) Trading off: the ecological effects of dam removal. Frontiers in Ecology and the Environment $1: 15-22$

Tiner RW (1999) Wetland indicators: a guide to wetland identification, delineation, and mapping. Lewis Publishers, New York
U.S Bureau of Reclamation. (2005). http://www.usbr.gov/ dataweb/dams/co01659.htm

USDA-NRCS (2004) The PLANTS Database, Version 3.5 (http://plants.usda.gov). National Plant Data Center, Baton Rouge, Louisiana

Weber WA (1990) Colorado flora: eastern slope. University Press of Colorado, Niwot

Wohl EE, Cenderelli DA (2000) Sediment deposition and transport patterns following a reservoir sediment release. Water Resources Research 36:319-333

Zuellig RE, Kondratieff BB, Rhodes HA (2002) Benthos recovery after an episodic release into a Colorado Rocky Mountain river. Western North American Naturalist 62:5972 